\title{
Quantifying climate change impacts emphasises the importance of managing regional threats in the endangered Yellow-eyed penguin
}

Thomas Mattern ${ }^{\text {Corresp., }}{ }^{1,2}$ ， Stefan Meyer ${ }^{1}$ ， Ursula Ellenberg ${ }^{2}$ ， David M Houston ${ }^{3}$ ， John T Darby $^{4}$, Melanie Young ${ }^{5}$, Yolanda van Heezik ${ }^{1}$, Philip J Seddon ${ }^{1}$

1 Department of Zoology, University of Otago, Dunedin, New Zealand

2 Department of Ecology, Environment and Evolution, La Trobe University, Melbourne, Australia

${ }^{3}$ Science and Policy Group, Department of Conservation, Auckland, New Zealand

4 Otago Museum, Dunedin, New Zealand

5 Department of Zoology, University of Otago, University of Otago, Dunedin, New Zealand

Corresponding Author: Thomas Mattern

Email address: t.mattern@eudyptes.net

Climate change is a global issue with effects that are difficult to manage at a regional scale. Yet more often than not climate factors are just some of multiple stressors affecting species on a population level. Non-climatic factors - especially those of anthropogenic origins - may play equally important roles with regard to impacts on species and are often more feasible to address. Here we assess the influence of climate change on population trends of the endangered Yellow-eyed penguin (Megadyptes antipodes) over the last 30 years, using a Bayesian model. Sea surface temperature (SST) proved to be the dominating factor influencing survival of both adult birds and fledglings. Increasing SST since the mid-1990s was accompanied by a reduction in survival rates and population decline. The population model showed that $33 \%$ of the variation in population numbers could be explained by SST alone, significantly increasing pressure on the penguin population. Consequently, the population becomes less resilient to non-climate related impacts, such as fisheries interactions, habitat degradation and human disturbance. However, the extent of the contribution of these factors to declining population trends is extremely difficult to assess principally due to the absence of quantifiable data, creating a discussion bias towards climate variables, and effectively distracting from non-climate factors that can be managed on a regional scale to ensure the viability of the population. 
1 Quantifying climate change impacts emphasises the importance

2 of managing regional threats in the endangered Yellow-eyed

3 penguin

4 Thomas Mattern ${ }^{1,2,}$, Stefan Meyer ${ }^{1}$, Ursula Ellenberg' ${ }^{2}$, David M. Houston ${ }^{3}$, John

5 T. Darby ${ }^{4}$, Melanie Young ${ }^{1}$, Yolanda van Heezik ${ }^{1}$, Philip J. Seddon ${ }^{1}$

$6{ }^{1}$ Department of Zoology, PO Box 56, University of Otago, Dunedin, New Zealand

$7 \quad 2$ Department of Ecology, Environment and Evolution, La Trobe University, Melbourne,

8 Australia

$9{ }^{3}$ Science and Policy Group, Department of Conservation, Private Bag 68 908, Newton,

10 Auckland, New Zealand

114 Otago Museum, P0 Box 6202, Dunedin, New Zealand

12 Corresponding author: Thomas Mattern ${ }^{1,2}$

13 Email address: t.mattern@eudyptes.net 


\section{Abstract}

15 Climate change is a global issue with effects that are difficult to manage at a regional scale.

16 Yet more often than not climate factors are just some of multiple stressors affecting species

17 on a population level. Non-climatic factors - especially those of anthropogenic origins -

18 may play equally important roles with regard to impacts on species and are often more

19 feasible to address. Here we assess the influence of climate change on population trends of

20 the endangered Yellow-eyed penguin (Megadyptes antipodes) over the last 30 years, using a

21 Bayesian model. Sea surface temperature (SST) proved to be the dominating factor

22 influencing survival of both adult birds and fledglings. Increasing SST since the mid-1990s

23 was accompanied by a reduction in survival rates and population decline. The population

24 model showed that $33 \%$ of the variation in population numbers could be explained by SST

25 alone, significantly increasing pressure on the penguin population. Consequently, the

26 population becomes less resilient to non-climate related impacts, such as fisheries

27 interactions, habitat degradation and human disturbance. However, the extent of the

28 contribution of these factors to declining population trends is extremely difficult to assess

29 principally due to the absence of quantifiable data, creating a discussion bias towards

30 climate variables, and effectively distracting from non-climate factors that can be managed

31 on a regional scale to ensure the viability of the population. 


\section{Introduction}

33 Climate change significantly alters the phenology and distribution of the world's fauna and

34 flora (Parmesan 2006). Species with spatially limited distributions suffer particularly from

35 climate-related change in their habitats, which can drive range shifts (e.g. Sekercioglu et al.,

36 2008; Grémillet \& Boulinier, 2009), range restrictions (Sexton et al., 2009) or, in the worst

37 case, extinction (Thomas et al., 2004). Current climate predictions suggest that the

38 pressure on ecosystems will continue to increase (Stocker, 2014), especially affecting

39 species that occupy fragmented habitats. The spatial segregation of suitable habitat might

40 preclude range shift adjustments and increase the risk of local extinctions (Opdam \&

41 Wascher, 2004).

42 For species conservation, this creates a daunting scenario. With resources for conservation

43 often limited, the inevitability of climate change could be used as an argument against

44 taking action to conserve species at locations that may become sub-optimal due to

45 environmental change (Sitas, Baillie \& Isaac, 2009). However, often cumulative

46 anthropogenic impacts (e.g. habitat destruction, pollution, resource competition, accidental

47 mortality) significantly add to - or even exceed - the impact of climate-related

48 environmental change (Parmesan \& Yohe, 2003; Trathan et al., 2015). While climate

49 change is a global issue that is difficult to tackle at a regional scale, addressing local-scale

50 anthropogenic factors can enhance species' resilience to environmental change.

51 Quantifiable data on climate variables are usually readily available through international

52 and regional monitoring programmes (e.g. Kriticos et al., 2012), whereas this is generally

53 not the case with other non-climate related data. Lack of monitoring or commercial 
54 interests often prevent the compilation of data (e.g. Chen, Chen \& Stergiou, 2003; Mesnil et

55 al., 2009) which may be relevant to species survival. This creates the risk of an analytical

56 bias towards climate impacts, thereby distracting from and potentially understating non-

57 climate threats.

58 The population status of New Zealand's endemic Yellow-eyed penguin (YEP, Megadyptes

59 antipodes) illustrates the complexity of this issue. YEP is a species of significant cultural and

60 economic value for New Zealand (Seddon, Ellenberg \& van Heezik, 2013). Particularly the

61 tourism industry of the Otago Peninsula benefits from the presence of the birds with an

62 annual contribution per breeding pair to the local economy estimated at about NZ\$250,000

63 (Tisdell, 2007). Ensuring the survival of the species is therefore not only a matter of ethical

64 considerations, but also of economic importance.

65 With an estimated 1,700 breeding pairs the YEP is one of the rarest penguin species world-

66 wide (Garcia Borboroglu \& Boersma, 2013). Compared to other penguins, the YEP's

67 distributional range is fairly limited. About $60 \%$ of the species' population is thought to

68 inhabit the sub-Antarctic Auckland and Campbell Islands, while the remaining 40\% breed

69 along the south-eastern coastline of New Zealand's South Island (Seddon, Ellenberg \& van

70 Heezik, 2013). Genetic analyses revealed that there is virtually no gene flow between the

71 sub-Antarctic and mainland YEP populations (Boessenkool et al., 2009a).

72 While little is known about the sub-Antarctic populations, mainland YEPs have received

73 considerable scientific attention. The first comprehensive studies of breeding biology and

74 population dynamics were carried out in the first half of the $20^{\text {th }}$ century by Lance Richdale

75 (Richdale, 1949, 1951, 1957). Interest in the species waned after Richdale's retirement 
76 from active research, but was rekindled in the late 1970s (Darby, 1985). Regular

77 monitoring of some breeding sites commenced in the early 1980s, and was expanded and

78 intensified following a catastrophic die-off affected breeding adult penguins on the Otago

79 Peninsula in the austral summer of 1989-90 (Efford, Spencer \& Darby, 1994). Parts of the

80 population have been monitored without interruption since 1982 resulting in a data set

81 spanning more than three decades (Ellenberg \& Mattern, 2012). A recent review of

82 available information revealed that a steady decline of the population might have been

83 masked by more intensive monitoring since the early 2000s (Ellenberg \& Mattern, 2012).

84 Most New Zealand penguin species including YEPs are believed to have undergone

85 significant population declines in the past century, with climate change suspected to be

86 playing a major role (e.g. Cunningham \& Moors, 1994; Peacock, Paulin \& Darby, 2000). At

87 the same time, penguin populations are exposed to numerous anthropogenic threats

88 (Trathan et al., 2015). Climate variables and anthropogenic influences create a complex mix

89 of factors that make it challenging to decipher the causation of population developments.

90 Using population data recorded between 1982 and 2015 from one of the YEP's mainland

91 strongholds, we developed a population model that integrates observed population

92 changes with key climatic variables. While climate data are readily available as continuous

93 data sets, data on anthropogenic factors are often sparse or of low temporal and spatial

94 resolution which inhibits quantitative analysis. We assess to which extent population

95 trends can be attributed to climate change so as to highlight and discuss the likely

96 importance of other, not readily quantifiable but more manageable threats. 


\section{Methods}

\section{Species information}

99 The IUCN Red list classifies Yellow-eyed penguins as "Endangered" (BirdLife International 100 2012), and they are listed as "Nationally Vulnerable" under the New Zealand Threat

101 Classification System (Robertson et al., 2013). The three main subpopulations are

102 estimated to range between 520-570 breeding pairs on the Auckland Islands, 350-540

103 pairs on Campbell Island, and 580-780 pairs along New Zealand's south-eastern coastlines

104 and Stewart Island (Seddon, Ellenberg \& van Heezik, 2013). On the mainland, the Otago

105 Peninsula represents the species' stronghold where numbers of breeding pairs in the past

106 three decades have been as high as 385 in 1996, but have steadily declined over the last 20

107 years to only 108 pairs in 2011 (Ellenberg \& Mattern, 2012).

108 Yellow-eyed penguins breed in the austral summer (September-February) so that their

109 annual breeding period spans the turn of the calendar year. Socialising and courtship in

110 July marks the onset of a new breeding season that ends in March/April with annual moult

111 and subsequent replenishing of resources in preparation for the next breeding season

112 (Seddon, Ellenberg \& van Heezik, 2013). Hence, we used austral year (i.e. July to June) to

113 calculate means and for summarising annual statistics of demographic and environmental

114 parameters.

\section{Study sites}

116 The Otago Peninsula penguin population has received considerable scientific attention in

117 the past century, with Richdale conducting his seminal population research between 1936

118 and 1954 (Richdale, 1949, 1951, 1957), followed by a string of projects from the 1980s 
119 onwards addressing many aspects of the Yellow-eyed penguin's biology including

120 phylogeny (e.g. Boessenkool et al., 2009b), breeding biology (e.g. Darby, Seddon \& Davis,

121 1990), diet (e.g. van Heezik, 1990), foraging ecology (e.g. Mattern et al., 2007), and

122 conservation (e.g. (Ellenberg, Mattern \& Seddon, 2013)). While Richdale conducted most of

123 his work at Kumo Kumo Whero Bay, most of the recent research was carried out at the

124 Boulder Beach complex (Fig 1) which, as a result, has the longest ongoing population

125 monitoring program and the most reliable data set available (Ellenberg \& Mattern, 2012).

126 Population monitoring \& Yellow-eyed penguin database (YEPDB)

127 Flipper banding of Yellow-eyed penguins commenced at Boulder Beach in the 1970s and by

128 the mid-1980s the majority of the local population was marked. Annual nest searches were

129 conducted to determine number of breeders and repeated nest checks provided

130 information on bird identity and reproductive success (Darby, 1985). After a catastrophic

131 adult die-off during the 1989 breeding season (Gill \& Darby, 1993), monitoring was

132 intensified to include $60 \%$ of the known South Island breeding sites (Seddon, Ellenberg \&

133 van Heezik, 2013). The Yellow-eyed penguin database (YEPDB) was created in the early

134 1990s (Efford, Spencer \& Darby, 1994) and is maintained by the New Zealand Department

135 of Conservation (DOC) which also maintains the YEP monitoring and banding program.

136 While the use of subcutaneous transponders has been introduced in the monitoring

137 population, DOC still maintains flipper bands as primary marking method for a transitional

138 period to ensure data consistency can be maintained before phasing out banding.

139 At the time of writing, the database contained banding records for 13,788 penguins (date

140 range: 1973-2013), and 9,006 nest records (range: 1979-2014). It also holds information 
141 on incidental penguin recoveries or sightings outside the breeding season; however, these

142 recovery data are patchy and were deemed too unreliable for analysis.

\section{Data}

\section{Demographic data}

145 Nearly one third of all banding records $(n=3,733)$ and nest records $(n=2,342)$ originate

146 from Boulder Beach (Fig 1) providing consistent, uninterrupted monitoring data for our

147 analyses. While monitoring commenced in the late 1970s, first complete data sets are

148 available from 1982 onwards, although for the first season there are only records of six

149 nests.

150 Data were extracted from YEPDB as a series of SQL queries. Population numbers were

151 retrieved from the table holding nest records. Number of breeding adults was calculated by

152 multiplying the number of nests by two; number of fledglings is the sum of chicks fledged

153 from all nests, and number of new breeders represents the sum of all adults that were

154 recorded for the first time as breeders. Where possible we determined age of breeding

155 birds per year by querying their banding details; age is unknown for birds banded as adults

156 (ca. $15 \%$ of all banded birds).

157 To estimate demographic parameters, we first extracted ID numbers for individuals

158 banded at the Boulder Beach complex since 1982. Secondly, we identified the years in

159 which each bird was recorded as a breeding adult in the nest record table. Finally, we

160 compiled the information from both database queries into a table where each column

161 represented a nest year and rows comprised encounter histories for each individual. Birds

162 had to miss at least two consecutive breeding seasons before being defined as dead or 
163 senescent. In a small number of cases a bird was not recorded as a breeder for three or

164 more consecutive years before remerging as a nest occupant, but this applied to less than

$1651 \%$ of all birds.

\section{Environmental data}

167 We obtained monthly averages for selected climatic variables deemed likely to have an

168 influence on demographic parameters (Table 1). The National Climate Database (CliFlo,

169 http://cliflo.niwa.co.nz) has kept records from weather stations in Dunedin and the Otago

170 Peninsula continuously since the early $20^{\text {th }}$ century. Austral annual means were calculated

171 for each parameter (i.e. July - June) as well as for the months March to May, which covers

172 the penguins' annual moult and post-moult periods. During this time birds are particularly

173 susceptible to environmental perturbations due the increased energy requirements for

174 feather replacement (Croxall, 1982). Data on local sea surface temperatures (SST) were

175 obtained from the Portobello Marine Laboratory (University of Otago) which holds a near

176 continuous time series of daily measurements dating back to January 1953 . We calculated

177 the monthly SST anomaly by subtracting monthly means from the average value calculated

178 from all monthly means ranging from January 1953 to December 2014; annual SST

179 anomaly is the mean of monthly SST anomalies for the corresponding year. To examine for

180 potential lag effects of SST anomaly on prey availability (Beentjes \& Renwick, 2001), we

181 also examined SST anomalies shifted backwards in time by one and two years.

\section{Population model}

183 We estimated adult survival and fledgling survival by developing a Bayesian mark-

184 recapture (MR) model that incorporated effects of climate parameters. Chicks are only 
185 banded shortly before fledging, so that the MR model could not consider hatchlings that 186 died before they were marked (i.e. chick survival). Hence, fledgling survival was adjusted 187 by incorporating the proportion of chicks fledged to chicks hatched. We modelled survival 188 in any year as a random process ranging around a mean of zero within the bounds of a total 189 temporal variance. This allowed us to determine the relative importance of each climate 190 covariate in terms of percentage of total variance explained (Grosbois et al., 2008). For

191 models with covariates explaining at least $20 \%$ of the total variance, we estimated 192 posterior model probabilities using Gibbs Variable Selection (GVS, Tavecchia et al., 2016)

193 Subsequently, we modelled YEP population dynamics via a female-only model assuming a 194 birth-pulse population (Tang \& Chen, 2002). The effect of environmental factors on the 195 population growth rate was examined by using fixed survival rates (means) within the 196 population model, allowing it to approximate the deterministic population growth rate 197 between 1982 and 2014. Similarly, we estimated the population growth rate by changing 198 mean survival rates corresponding to low SSTs that were measured from 1982 to 1996, 199 and high SSTs characteristic for the time period from 1997 to 2015. Finally, we projected 200 future populations by running a series of stochastic projections that used a range of 201 survival rate estimates (i.e. omitting years with increasing uncertainty in estimate validity) 202 and predicted trends in influential environmental factors.

203 Detailed descriptions of all modelling procedures are provided as Electronic 204 Supplementary Material (ESM1). 


\section{Comparison with historic population trends}

206 Richdale (1957) provides comprehensive data on penguin demography allowing it to draw

207 comparisons between historic and contemporary penguin numbers. We inferred

208 population parameters from three tables. Table 67 (p147) provides direct information

209 about the number of eggs laid and chicks fledged. Using number of eggs, we inferred the

210 number of nests for the reported years by assuming only two-egg clutches were present. In

211 table 72 (p154), Richdale reports the percentage of surviving breeders of both sexes for

212 each year, adjusted to the fractional format by dividing the reported values by 100 . Finally,

213 table $62(\mathrm{p} 138)$ provides clues about annual recruitment, which was calculated as

214 proportion of new breeders each year. We omitted Richdale's data for the 1936 season and

215 for the seasons following 1949, as he noted less frequent monitoring and incomplete data

216 sets for the initial and the latter years of his study (Richdale 1957).

\section{Results}

\section{Observed penguin numbers}

219 Numbers of adult breeders at Boulder Beach fluctuated considerably between 1982 and

2202015 (Fig 2). Immigration of birds that had been banded outside Boulder Beach was a rare

221 occurrence throughout the study period (mean proportion of immigrants per year 1982-

222 2015: 2.7 $\pm 2.2 \%$ ). If birds banded as breeders are considered to have come from other

223 breeding sites, the median immigration is similar (2.0\%) although three years $(1991,2010$

224 and 2012) would stand out where unbanded adults made up 11, 10 and $8 \%$ of the breeding

225 population, respectively. An apparent rise in penguin numbers at the beginning of the

226 monitoring period (i.e. 1982-1985) reflects increasing monitoring effort. Reduced 
227 monitoring effort may explain the drop in numbers after 1985-86; two areas were not

228 monitored in several years (A1: 1986-1989; Highcliff: 1989). Both areas account for $46 \pm 4 \%$

229 of penguin counts (1990-2015), so that true penguin numbers in 1989 were likely

230 considerably higher than the database would suggest. Breeder numbers in the two areas

231 monitored in 1989 (Midsection; Double Bay) dropped by 62\% in the following season

232 (1989: 74 birds, 1990: 28 birds) when the population was affected by a catastrophic adult

233 die-off. The population recovered between 1990 and 1996 to reach levels comparable to

234 those observed in 1985. The 1996 season had the highest numbers of breeders recorded at

235 Boulder Beach ( $\mathrm{n}=242)$ and represents a turning point for the population. Subsequently

236 penguin numbers reached a low of 104 breeders in 2002, with losses compounded by

237 another adult die-off event occurring in the 2001 season. Between 2002 and 2012 the

238 population fluctuated between 100 and 150 breeders without any apparent trend before

239 another drastic decline in numbers began in the years following a third adult die-off event

240 at the end of the 2012 season. The steepest drop in numbers (41\%) recorded since 1989

241 occurred between 2013 (128 breeders) and 2014 (76 breeders). In 2015, only 58 breeding

242 penguins were recorded, which translates to a 76\% decline in numbers since 1996.

243 Number of chicks that fledged each year generally followed the trends observed for adults

244 (Fig. 2). However, significant variation between 2003 and 2010 reflects a series of years

245 with poor breeding success followed by better reproductive output in the following year.

246 Numbers of new breeders showed a similar albeit weakened pattern delayed by 5 years:

247 starting in 2004, numbers of new breeders seem to mimic those of fledglings beginning in 2481999. 
249 Age of breeding birds ranged between 8.4 years (1984) and 14.9 years (1990, mean:

$25012 \pm 1.4$ years, Fig. 3). Between 1990 and 2015 the average age of returning breeders

251 showed a slightly decreasing trend from around 14 to 11 years (Pearson correlation $\rho=-$

$\left.2520.307, t_{24}=-1.5781, p=0.13\right)$. At the same time, average age of new breeders dropped

253 significantly from more than 10 years in the 1990 s to only 4 years in $2015\left(\rho=-0.796, t_{24}=-\right.$

$2541.5781, p<0.001)$. The average age of new breeders increased steeply after both the 1989

255 and 2001 adult die-offs (Fig 3) indicating a substantial pool of older non-breeders ready to

256 recruit following the disappearance of established breeders. No such spike is apparent after

257 the 2012 die-off suggesting that the pool of older recruits has dried up over the last decade.

\section{Demographic estimates from the mark-recapture model}

259 The MR model without covariate revealed a fledgling survival rate of 0.12 (95\%, Credible

260 Interval: $0.08,0.19)$ in chicks (Table 2$)$. The survival of adults was 0.87 (95\%, CrI: 0.83,

261 0.90). Throughout the study period (1982-2014), fledgling survival varied 2.56 times more

262 than adult survival $(95 \%$, CrI: 1.03, 6.45) (Table 2).

263 Years with increased wind activity had a positive effect on fledgling survival, whereas the

264 effect of higher than normal SST was negative; both covariates explained 33.2\% of the

265 variance (Table 3a, ID $1 \&$ 2). Similarly, SST anomaly during the first three months after

266 fledging as well as in the previous year both had a negative effect on survival, explaining

$26724.8 \%$ and $17.4 \%$ of the variance (IDs $3 \& 4$ ), while increased wind activity in the months

268 after fledging had a positive effect on fledgling survival (16.5\% of variance explained, ID 5).

269 Furthermore, years with above average air temperatures had a negative effect on fledgling

270 survival, explaining $12.4 \%$ and $15.4 \%$ of the variance (IDs $6 \& 7$ ). 
271 In adults, SST had the greatest effect on the survival rate, explaining $36.8 \%$ of the variance

272 (Table 3b, ID 1). The relationship of adult survival and SST becomes apparent when the

273 deviation of annual adult survival from the median survival rate is plotted against SST

274 anomaly (Fig 4). In periods with cooler than usual SST, adult survival was high (e.g.1990-

275 1996), whereas warm periods were characterized by lower adult survival. The same was

276 true for air temperature. Warmer years were associated with reduced adult survival; air

277 temperature-related covariates explained $34.4 \%$ of the variation in adult survival (Table

2783 b, IDs $2 \& 3$ ).

279 Refitting the MR model with the two most influential explanatory covariates each for

280 fledging and adult survival, and subsequent assessment of posterior model probability,

281 ranked highest the model where both chick and adult survival were fitted to the single

282 covariate SST anomaly (Table 4).

\section{Predictions for the adult female population}

284 Using year-specific survival rates from the MR model generates predictions of numbers of 285 adults that were similar to those determined during monitoring. For most years, the 286 observation-based number of adult female YEPs and the 95\% credible intervals for the 287 predicted number of adult female YEPs overlapped (Fig 5).

288 Based on a deterministic model (i.e. without temporal variance in survival rates) the 289 population growth rate was $1.02(95 \% \operatorname{CrI} 0.98,1.06)$ per year throughout the entire study 290 period. For the time period when SST was below average (1982 to 1996, Fig. 4) the 291 population showed an increasing trend with a growth rate of $1.038(95 \% \mathrm{CrI} 0.99,1.080$, 292 Fig 6). However, from 1996 onwards an ongoing period of mainly warmer than normal SST 
293 went along with a growth rate of $0.94(95 \%$ CrI $0.90,0.98)$ indicating a population decline 294 (Fig 6).

\section{Future projections}

296 Based on projections of increasing SST at a rate of $0.02^{\circ} \mathrm{C}$ per year in the next decades

297 (Oliver et al. 2014), the penguin population at Boulder Beach will continue to decline.

298 Stochastic simulations using the most reliable estimates for adult survival (1982-2012)

299 suggest that the number of adult female penguins will drop below 10 individuals by 2048

300 (Fig 5a). If the recent poor breeding years 2013-2015 are included this negative trend gets

301 progressively worse (Fig 5b-d). Including adult survival rates estimated for 2015, the mean

302 projection predicts YEPs to be locally extinct by 2043.

\section{Discussion}

304 Numbers of Yellow-eyed penguins at Boulder Beach have declined since 1996 (Figs 5\&6).

305 The local population seemed to experience a reprieve from this decline in the first decade

306 of the new millennium, despite unfavourable climatic conditions at that time. This might

307 have been driven by a temporary reduction in other, non-climate negative impacts, the

308 nature of which remain unclear due to a lack of data.

309 The ages of breeding penguins provide some explanation about the underlying mechanics

310 of the population decline. In the years following the 1989 and 2001 adult die-offs, the

311 average age of new breeders recruited into the population was substantially higher than in

312 the years prior to the events. All of these birds were locally banded individuals, which

313 suggests that there was a pool of older, previously unpaired birds which replaced

314 experienced breeders that had died during the event. After the 2012 die-off, the mean age 
315 of new breeders reached an historic low (4.1 years, Fig 3). Hence, old breeders that had lost

316 their partner now paired up with younger penguins indicating that the pool of older non-

317 breeders available to replace lost birds had disappeared. This is supported by the number

318 of recruits reflecting the marked variation in fledgling numbers with a 5-year-lag (Fig 2). It

319 appears that since the turn of the century, penguins recruit into the breeding population at

320 the earliest possible opportunity. This likely has negative effects on breeding performance

321 since in seabirds age is an important determinant for foraging success (e.g. Daunt et al.,

322 2007; Zimmer et al., 2011) and subsequently reproductive success (e.g. Limmer \& Becker,

323 2009; Nisbet \& Dann, 2009). The decline in the mean age of new breeders in recent years

324 indicates that more inexperienced birds are recruiting as breeders, and possibly explains

325 the overall deteriorating reproductive success.

326 When the 2012 die-off of adult breeding birds occurred, penguin numbers were less than

$32760 \%$ of what they had been in the mid-1990s (Fig 2). While the penguin population showed

328 a remarkable recovery after the 1989 event this did not happen following 2012; instead

329 numbers have continued to decline. The most apparent differences following the two die-

330 offs are the trends in ocean temperatures with a cooler-than-normal period in the first half

331 of the 1990s whereas SST has been almost continuously higher than the 1953-2014

332 average since the late 1990s (Fig 4).

\section{Sea surface temperature effects}

334 Sea surface temperature explained 33\% of the variation in observed population trends.

335 Hence, SST has an important influence on YEP population trends. Years with warmer than 336 usual SST result in reduced adult survival, whereas the reverse is true when SST is cooler. 
337 Variation in SST likely influences the abundance and quality of YEP prey. In Little penguins

338 (Eudyptula minor) breeding on the Otago Peninsula, climatic fluctuations - and connected

339 to this, ocean temperatures - were found to affect prey composition (Perriman et al., 2000).

340 Little penguins are generalist foragers that take a variety of pelagic prey (Dann, 2013),

341 most likely a beneficial trait in relation to climate related change in resource abundance

342 (Thuiller, Lavorel \& Araújo, 2005). YEPs on the other hand, are principally benthic foragers

343 (Mattern et al., 2007) that feed predominantly on demersal species (e.g. van Heezik, 1990;

344 Moore \& Wakelin, 1997; Browne et al., 2011). Although this specialisation reduces

345 competition for pelagic prey with the abundant marine avifauna in New Zealand (Mattern

346 et al., 2007), it comes at the cost of reduced behavioural flexibility to respond to changes in

347 prey distribution or abundance (e.g. Browne et al., 2011; Mattern et al., 2013).

348 Temperature affects the annual biomass of many fish species in New Zealand (Beentjes \&

349 Renwick, 2001). Warmer than normal conditions negatively affect spawning in fish,

350 reducing subsequent recruitment (e.g. Takasuka, Oozeki \& Kubota, 2008). Abundance of

351 the demersal Red cod (Pseudophycis bacchus), historically an important prey species for

352 YEP from Boulder Beach (van Heezik, 1990; Moore \& Wakelin, 1997), shows a strong

353 correlation to SST fluctuations, albeit with a lag of 14 months (Beentjes \& Renwick, 2001).

354 At Boulder Beach, a reduction in body mass of breeding YEPs in 1985 when compared to

3551984 was associated with lower quantities of red cod taken (van Heezik \& Davis, 1990).

3561983 featured cooler than normal SST (mean monthly SST anomaly: -0.73), while 1984

357 temperatures were above average (SST anomaly: 0.17). As such the lagged correlation

358 between SST and red cod abundance reported by Beentjes \& Renwick (2001) also seems to

359 be manifested in penguin body condition. This explains the relative importance of the 
360 corresponding covariate (i.e. sst_anomaly_minus1year) for survival rates (Table $3 a \& b$ ) and

361 corresponds to findings of a previous analysis of climate variables on YEP numbers

362 (Peacock, Paulin \& Darby, 2000).

363 However, model selection showed an even stronger direct SST effect (Table 4). Ocean

364 temperatures play an important role in the spatial distribution of fish populations

365 (Beentjes et al., 2002). Warmer than usual SST is often an indication of increased

366 stratification of the water column where a layer of warmer water sits on top of cooler

367 water. This disrupts the benthic-pelagic coupling, i.e. mixing processes that regulate

368 nutrient flow between benthos and surface waters (Jones et al., 2014). Land run-off has

369 been identified as a major source of nutrients for the South Otago continental shelf, which

370 results in higher near-surface nutrient concentrations (Hawke, 1989), so that vertical

371 mixing is likely of crucial importance for benthic productivity and subsequent prey

372 abundance in the penguins' home ranges. Penguin foraging conditions are likely

373 compromised under stratified, warm-water conditions.

374 The three major die-offs of adult penguins (seasons 1989-90, 2001-02, and 2012-13) all

375 occurred in years with higher than normal SST suggesting that stratification might have

376 more severe impacts than can be explained by the disruption of nutrient fluxes alone.

\section{SST and relevance of die-off events}

378 Die-off events do not seem to be related to prey availability; body condition of adult

379 penguins examined during the 1989 event did not indicate malnutrition (Gill \& Darby,

380 1993). The cause of mortality could not be identified although necropsies after the 2012

381 die-off indicated it to be toxin related (Gartrell et al., 2016). Harmful algal blooms (HAB) 
382 that are known to have negative impacts on other penguin species (Shumway, Allen \&

383 Boersma, 2003) were suspected to be involved in the die-offs as well (Gill \& Darby, 1993).

384 Yet water samples taken along a transect through the penguin's known foraging ranges

385 found no evidence for the presence of harmful algae (Mattern et al, unpublished data).

386 Tests for the presence of marine biotoxins in freshly dead birds were negative (Gartrell et

387 al., 2016). Moreover, it seems unlikely that a HAB would selectively affect only one seabird

388 species (Shumway, Allen \& Boersma, 2003); no other unexplained seabird deaths occurred

389 during any of the die-offs. Only bottom foraging YEPs were affected suggesting that the

390 distribution of a toxin was probably limited to the near-seafloor region. Stratification and

391 the disruption of vertical mixing potentially would contribute to a concentration of toxic

392 components at the sea floor. While the origin or exact nature of the toxin remains unclear,

393 it could be related to technical malfunctions that occurred at the time at Dunedin's sewage

394 treatment plant, which discharges at the seafloor about $1.5 \mathrm{~km}$ from the shore and ca. $5 \mathrm{~km}$

395 upstream from Boulder Beach (Dunedin City Council, unpublished data).

396 Although the cause of die-off events remains a matter of speculation, their relevance for

397 population trends is closely tied to prevalent environmental conditions following these

398 events. The 1989 die-off, which removed about 50\% of penguins from the breeding

399 population (Efford, Spencer \& Darby, 1996) was followed by a six year period of population

400 recovery, likely aided by cooler than normal SST (Fig. 4). The next die-off event occurred at

401 Boulder Beach in 2001 (Alvin Setiawan, pers. comm.) and reduced the local population by

402 nearly $40 \%$. Following this event, the population showed no sign of recovery during a

403 prolonged period of warmer-than-normal SST that began in 1998 and prevails until today.

404 The associated reduced adult survival explains the lack of recovery in the penguin 
405 population. Consequently, the 2012 die-off had a cumulative effect, further reducing the 406 population to its lowest level on record.

407 With projected SST increases over the next decades it seems doubtful that optimal marine 408 conditions supporting the recovery of YEPs will occur in the future. Hence, future die-off 409 events will be increasingly critical for penguin numbers. However, sea surface

410 temperatures only explained about one third of the variation in survival rates. This means 411 that other factors also play important roles for YEP population dynamics.

\section{Other climate factors}

413 Daily minimum air temperature is a proxy for prevailing temperature regimes, where a

414 higher average minimum temperature indicates warmer years. Air temperature could 415 simply be a covariate of SST and affect penguin survival through the mechanisms suggested 416 above. In addition, air temperatures recorded during the moult (March-May) negatively 417 affected adult survival probably as a result of hyperthermia. Little penguins in Australia 418 suffer increased adult mortality when exposed to higher temperatures when moulting 419 (Ganendran et al., 2015). However, there is no evidence for comparable temperature420 related mortality events in YEP

421 Frequency of days with strong winds had a positive influence on fledgling survival. Wind 422 aids oceanic mixing processes and thereby can become a driver for foraging success in 423 penguins (Dehnhard et al., 2013). Wind generally acts as an antagonist to SST-related

424 stratification effects, creating enhanced foraging conditions for penguins thereby

425 increasing the survival chances of inexperienced fledglings. 


\section{Non-climate factors}

427 In this study we were able to use comprehensive data to test the influence of a wide range

428 of climate related factors on the population developments of Yellow-eyed penguins from

429 Boulder Beach. Yet only about a third of the variation in penguin numbers can be explained

430 by climate factors. Hence, it is clear that other, non-climate factors significantly affect

431 penguin survival rates. While several of these factors are well known, it is impossible to

432 examine their impact on the penguin population in a modelling context due to a lack of any

433 quantifiable data. At the same time, unlike the effects of climate change, at least some of

434 these non-climatic factors could be managed on a regional scale to enhance the species'

435 chance for survival. Therefore it is imperative to discuss some of these non-climate factors

436 to avoid an undue focus on only the quantifiable factors (i.e. those driven by climate

437 change) and direct conservation management towards measures that can ensure

438 persistence of the Yellow-eyed penguin on the New Zealand mainland.

\section{Fisheries interactions}

440 Potential impacts of incidental bycatch in gill net fisheries (Darby \& Dawson, 2000) and

441 alteration of the penguins' benthic foraging habitat by bottom fishing activities (Ellenberg

442 \& Mattern, 2012; Mattern et al., 2013) could not be quantified because data on gill net

443 fisheries supplied by the Ministry of Primary Industries (NZ Ministry Of Primary Industries,

444 Official Information Act Request OIA12-397) proved to be spatially coarse and temporally

445 limited, with approximate locations of gill net fishing events specified only from 2006

446 onwards. Provided data on bottom fishing effort only covered the years 2000-2012 and

447 originated from vessels operating outside the penguins' ranges (OIA12-460). 
448 The impact of single fisheries interactions might have a much greater effect on penguin

449 numbers than annual fishing statistics would suggest. There are reports of multiple YEP

450 killed in a single gill net haul (Ellenberg \& Mattern, 2012) and reported bycatch incidents in

451 gill net fisheries have been as high as 12 cases per year, many of which affected YEPs from

452 the Otago Peninsula (Darby \& Dawson, 2000). Currently, less than $2 \%$ of gill net effort in

453 New Zealand is being independently observed (Richard \& Abraham, 2015); this lack of

454 observer coverage prevents reliable quantification of bycatch mortality. Yet it stands to

455 reason that incidental fisheries mortality is an important factor affecting penguin survival

456 rates and, hence, population trends.

457 Impacts of bottom fishing activities on YEP survival are even more difficult to quantify.

458 Bottom trawling and dredge fisheries can substantially alter the benthic environment,

459 reducing biodiversity, and prey abundance and quality for YEPs (Ellenberg \& Mattern,

460 2012). Low quality prey were brought ashore by YEPs on Stewart Island, which had home

461 ranges that apparently avoided the vast areas of potential habitat subject to intensive

462 oyster dredging (Browne et al., 2011; Ellenberg \& Mattern, 2012). On the Otago Peninsula,

463 some penguins forage along straight-line paths following bottom trawl scrape marks,

464 searching for scavenging prey that appears to be inadequate food for young chicks

465 (Mattern et al., 2013).

\section{Disease outbreaks}

467 In the past decade several breeding seasons saw the occurrence of diphtheritic stomatitis, 468 a secondary infection negatively affecting chick survival (Houston \& Hocken, 2005). We

469 could not test the effects of such disease outbreaks on population trends, because the YEP 
470 database does not facilitate quantitative storage of disease-related data. Diphtheritic

471 stomatitis only affects chicks which generally survive when older than 2 weeks (Alley et al.,

472 2016). So the disease is unlikely to have a lasting effect on population trends as it does not

473 affect adults which are critical for the maintenance of a stable population (Benton \& Grant,

474 1999). Although YEPs are subject to exposure to avian malaria parasites (Graczyk et al.,

475 1995), observed infections are low, hence, avian malaria currently does not present a

476 significant problem for the species (Sturrock \& Tompkins, 2007). Avian pox which is

477 caused significant mortality events in Magellanic (Spheniscus magellanicus) and possibly

478 Gentoo penguins (Pygoscelis papua) has not been observed in Yellow-eyed penguin,

479 although diphtheritic stomatitis may be the result of a secondary bacterial infection caused 480 by a poxvirus (Alley et al., 2016).

\section{Predators}

482 Introduced terrestrial predators are one of the biggest challenges for native wildlife in New 483 Zealand (Wilson, 2004). Mustelids (Mustela sp.), dogs (Canis lupus familiaris), and to a 484 lesser extent cats (Felis catus) and rats (Rattus sp.) can impact on YEP (e.g. Alterio, Moller \& 485 Ratz, 1998; Ratz \& Murphy, 1999), but it is very difficult to quantify these effects because 486 direct evidence of predation is sparse. A five year study investigating the impact of feral 487 cats on penguins on Stewart Island did not find any indication for predation events and 488 concluded that starvation and disease were the main factor of mortality (King, 2008). On 489 the mainland, predation by dogs or stoats appear to be very localised occurrences (Hocken, 490 2005). However, climate change may render this an increasing problem in the future 491 (Tompkins, Byrom \& Pech, 2013) 
492 Predation by the native NZ sea lion (Phocarctos hookeri) has to date been limited to two

493 female sea lions that were active between 1997 and 2005 (Lalas et al., 2007) that have

494 since died (Jim Fyfe, pers. com.). More recently, a number of YEPs have been reported with

495 injuries that were speculated to have been inflicted by Barracouta (Thyrsites atun).

496 Considering that barracouta are smaller than adult YEPs (mean body lengths - barracouta:

$49755 \mathrm{~cm}$, Fishbase.org 2016; YEPs: $65 \mathrm{~cm}$, Seddon, Ellenberg \& van Heezik, 2013) such

498 injuries are at best an accidental consequence of penguins and fish targeting the same prey

499 patch. Some external injuries might be the result of interactions with humans; in Australia,

500 Little penguins (Eudyptula minor) have been injured and killed by water craft such as jet

501 skis (Cannell et al., 2016), a recreational activity that has also been observed in the penguin

502 landing zone at Boulder Beach (pers. obs).

\section{Human impacts}

504 The significance of human impacts in the form of deforestation of breeding habitat, capture 505 by collectors, egging, and shooting of adults on the YEP population was highlighted early by 506 Richdale (1952). While these impacts are no longer an issue, unregulated tourism has

507 become an important threat at some Yellow-eyed penguin colonies and is reflected in

508 reduced breeding performance and a steady decline of local penguin numbers (e.g.

509 McClung et al., 2004; Ellenberg et al., 2007; Ellenberg, Mattern \& Seddon, 2009).

\section{Maladapted colonizer?}

511 Comprehensive analysis of ancient penguin DNA in recent years have revealed that YEP is 512 relatively recent colonizer originating from sub-Antarctic. The species is believed to have 513 replaced a sister taxon Megadyptes waitaha after it was hunted to extinction by humans as 
514 recently as 500 years ago (Boessenkool et al., 2009b; Rawlence et al., 2015). In this light,

515 the question was raised whether the species' vulnerability to increasing ocean

516 temperatures may in fact reflect a maladaptation for a warmer climate (Waters \& Grosser,

517 2016). While evidence for a physiological relationship between ocean warming and

518 survival rates in YEP is lacking, the specialized benthic foraging strategy renders the

519 species particularly sensitive to environmental change (Mattern et al., 2007; Gallagher et

520 al., 2015). With the various non-climatic factors discussed above all contributing to

521 significant shifts across the entire benthic ecosystem, reducing the penguins' struggle to a

522 species-specific maladaptation for a warming climate clearly oversimplifies the matter.

\section{Conservation implications}

524 Stochastic simulations of future population trends for Yellow-eyed penguins at Boulder

525 Beach, show that the population will continue to decline if current threats continue

526 unabated. Global ocean temperatures are rising (Stocker, 2014); projections for the

527 Tasman region until 2060 predict an increase in SST of up to $2^{\circ} \mathrm{C}$ (Oliver et al., 2014), hence

528 future climatic conditions will not be favorable for a recovery of the YEP population.

529 On the bright side, climate change-related pressure on YEP can likely be offset through

530 control of the other more manageable factors negatively affecting population trends. This

531 has already been demonstrated: positive YEP population growth during the 1940s, at a

532 time when SST was strongly increasing in the Pacific to levels comparable to those

533 recorded in the 1990s (Guan \& Nigam, 2008), was attributed to a reduction in human

534 impacts such as conversion of breeding habitat to farm land, establishment of road

535 networks, road traffic and random acts of violence (Richdale, 1957). During World War II, 
536 when resources were directed towards the war effort, 'man's destructive agencies were

537 practically negligible' (Richdale, 1957, p157).

538 While climate change is a global phenomenon that is both inevitable and quantifiable, it is

539 important to bear in mind its impact on species population trends is relative to other more

540 regional factors, such as, in the case of penguins, fisheries, pollution, habitat destruction,

541 introduced terrestrial predators, and human disturbance (Trathan et al., 2015). Managing

542 local and regional factors can increase the resilience of species towards increasing pressure

543 from climate change.

544 The virtual absence of quantifiable data to examine the effects of non-climate factors makes

545 it difficult to provide fact-based management recommendations and puts a potentially

546 overbearing emphasis on climate change. However, these principally anthropogenic factors

547 likely also explain significant portions of the variation in survival rates, so that the focus

548 should be on improving our understanding and management of these impacts to enhance

549 this species' resilience to climate change.

\section{Acknowledgements}

551 We would like to extend our gratitude to the many field workers and students involved in

552 penguin monitoring that contributed data to the YEPDB. Special thanks are due to Bruce

553 McKinlay, Jim Fyfe, and Jim Watts from the Department of Conservation Coastal Otago

554 office for their efforts to maintain a regular monitoring schedule in the face of limited 555 resources within the department. 


\section{References}

557 Alley M., Suepaul R., McKinlay B., Young M., Wang J., Morgan K., Hunter S., GArtrell B. 2016.

558 Diphtheritic stomatitis in Yellow-eyed penguins (Megadyptes antipodes) in New Zealand. $559 \quad$ Journal of Wildlife Diseases 53:102-110.

560 Alterio N., Moller H., Ratz H. 1998. Movements and habitat use of feral house cats Felis catus, stoats 561 Mustela erminea and ferrets Mustela furo, in grassland surrounding yellow-eyed penguin 562 Megadyptes antipodes breeding areas in spring. Biological Conservation 83:187-194.

563 Beentjes MP., Bull B., Hurst RJ., Bagley NW. 2002. Demersal fish assemblages along the continental 564 shelf and upper slope of the east coast of the South Island, New Zealand. New Zealand Journal 565 of Marine and Freshwater Research 36:197-223.

566 Beentjes MP., Renwick JA. 2001. The relationship between red cod, Pseudophycis bachus, 567 recruitment and environmental variables in New Zealand. Environmental Biology of Fishes $568 \quad 61: 315-328$.

569 Benton TG., Grant A. 1999. Elasticity analysis as an important tool in evolutionary and population $570 \quad$ ecology. Trends in Ecology \& Evolution 14:467-471. DOI: 10.1016/S0169-5347(99)01724-3.

571 Boessenkool S., Star B., Waters JM., Seddon PJ. 2009a. Multilocus assignment analyses reveal 572 multiple units and rare migration events in the recently expanded yellow-eyed penguin 573 (Megadyptes antipodes). Molecular Ecology 18:2390-2400.

574 Boessenkool S., Austin JJ., Worthy TH., Scofield P., Cooper A., Seddon PJ., Waters JM. 2009b. Relict or 575 colonizer? Extinction and range expansion of penguins in southern New Zealand. Proceedings. 576 Biological sciences / The Royal Society 276:815-821.

577 Browne T., Lalas C., Mattern T., Van Heezik Y. 2011. Chick starvation in yellow-eyed penguins: 
578 Evidence for poor diet quality and selective provisioning of chicks from conventional diet

579 analysis and stable isotopes. Austral Ecology 36:99-108. DOI: 10.1111/j.1442-

$580 \quad 9993.2010 .02125 . x$.

581 Cannell BL., Campbell K., Fitzgerald L., Lewis JA., Baran IJ., Stephens NS. 2016. Anthropogenic

582 trauma is the most prevalent cause of mortality in Little Penguins, Eudyptula minor, in Perth,

583 Western Australia. Emu 116:52-61. DOI: 10.1071/MU15039.

584 Chen Y., Chen L., Stergiou KI. 2003. Impacts of data quantity on fisheries stock assessment. Aquatic

585 Sciences 65:92-98. DOI: 10.1007/s000270300008.

586 Croxall JP. 1982. Energy costs of incubation and moult in petrels and penguins. The Journal of $587 \quad$ Animal Ecology:177-194.

588 Cunningham DM., Moors PJ. 1994. The Decline of Rockhopper Penguins Eudyptes chrysocome at 589 Campbell Island, Southern Ocean and the Influence of Rising Sea Temperatures. Emu 94:27$590 \quad 36$.

591 Dann P. 2013. Little Penguin (Eudyptula minor). In: Garcia Borboroglu P, Boersma PD eds.

592 Penguins: Natural History and Conservation. Seattle \& London: University of Washington Press, $593 \quad 304-319$.

594 Darby JT. 1985. The great yellow-eyed penguin count. Forest \& Bird 16:16-18.

595 Darby JT., Dawson SM. 2000. Bycatch of yellow-eyed penguins (Megadyptes antipodes) in gillnets in 596 New Zealand waters 1979-1997. Biological Conservation 93:327-332.

597 Darby JT., Seddon PJ., Davis LS. 1990. Breeding biology of Yellow-eyed Penguins (Megadyptes 598 antipodes). In: Davis LS., Darby, JT. eds. Penguin Biology. San Diego, California: Academic 599 Press, 
600 Daunt F., Wanless S., Harris MP., Money L., Monaghan P. 2007. Older and wiser: improvements in 601 breeding success are linked to better foraging performance in European shags. Functional $602 \quad$ Ecology 21:561-567.

603 Dehnhard N., Ludynia K., Poisbleau M., Demongin L., Quillfeldt P. 2013. Good Days, Bad Days: Wind 604 as a Driver of Foraging Success in a Flightless Seabird, the Southern Rockhopper Penguin. PloS 605 ONE 8:e79487. DOI: 10.1371/journal.pone.0079487.

606 Efford MG., Spencer N., Darby JT. 1994. A relational database for Yellow-eyed penguin banding and 607 breeding records. unpublished report: Landcare Research, Dunedin, New Zealand.

608 Efford MG., Spencer NJ., Darby JT. 1996. Population studies of Yellow-eyed penguins - 1994-94 609 progress report. unpublished report: Department of Conservation, Wellington, New Zealand.

610 Ellenberg U., Setiawan AN., Cree A., Houston DM., Seddon PJ. 2007. Elevated hormonal stress response and reduced reproductive output in Yellow-eyed penguins exposed to unregulated

613 Ellenberg U., Mattern T. 2012. Yellow-eyed penguin - review of population information. Wellington,

614 New Zealand: Department of Conservation. DOI: 10.13140/RG.2.2.21606.83523.

615 Ellenberg U., Mattern T., Seddon P. 2009. Habituation potential of yellow-eyed penguins depends on 616 sex, character and previous experience with humans. Animal Behaviour 77:289-296. DOI: 617 10.1016/j.anbehav.2008.09.021.

618 Ellenberg U., Mattern T., Seddon PJ. 2013. Heart rate responses provide an objective evaluation of 619 human disturbance stimuli in breeding birds. Conservation Physiology 1:cot013.

620 Gallagher AJ., Hammerschlag N., Cooke SJ., Costa DP., Irschick DJ. 2015. Evolutionary theory as a tool 621 for predicting extinction risk. Trends in ecology \& evolution 30:61-65. 
622 Ganendran LB., Sidhu LA., Catchpole EA., Chambers LE., Dann P. 2015. Effects of ambient air

623 temperature, humidity and rainfall on annual survival of adult little penguins Eudyptula minor

624 in southeastern Australia. International Journal of Biometeorology:1-9. DOI: 10.1007/s00484-

$625 \quad 015-1119-2$.

626 Garcia Borboroglu P., Boersma PD. 2013. Penguins: Natural History and Conservation. University of 627 Washington Press.

628 Gartrell B., Agnew D., Alley M., Carpenter T., Ha HJ., Howe L., Hunter S., McInnes K., Munday R., 629 Wendi R., Melanie Y. 2016. Investigation of a mortality cluster in wild adult yellow-eyed 630 penguins (Megadyptes antipodes) at Otago Peninsula, New Zealand. Avian Pathology 0:1-26.

$631 \quad$ DOI: $10.1080 / 03079457.2016 .1264568$.

632 Gill JM., Darby JT. 1993. Deaths in yellow-eyed penguins (Megadyptes antipodes) on the Otago 633 Peninsula during the summer of 1990. New Zealand Veterinary Journal 41:39-42.

634 Graczyk TK., Cranfield MR., Brossy JJ., Cockrem JF., Jouventin P., Seddon PJ. 1995. Detection of avian 635 malaria infections in wild and captive penguins. Journal of the Helminthological Society of $636 \quad$ Washington 62:135-142.

637 Grémillet D., Boulinier T. 2009. Spatial ecology and conservation of seabirds facing global climate 638 change: a review. Marine Ecology Progress Series 391:121-137.

639 Grosbois V., Gimenez O., Gaillard J., Pradel R., Barbraud C., Clobert J., Møller AP., Weimerskirch H. 640 2008. Assessing the impact of climate variation on survival in vertebrate populations.

641 Biological Reviews 83:357-399.

642 Guan B., Nigam S. 2008. Pacific sea surface temperatures in the twentieth century: An evolution643 centric analysis of variability and trend. Journal of Climate 21:2790-2809. DOI:

$644 \quad$ 10.1175/2007JCLI2076.1. 
645 Hawke DJ. 1989. Hydrology and near-surface nutrient distribution along the South Otago

646 continental shelf, New Zealand, in summer and winter 1986. New Zealand Journal of Marine

647 and Freshwater Research 23:411-420.

648

van Heezik Y. 1990. Seasonal, geographical, and age-related variations in the diet of the Yellow-eyed

649 Penguin (Megadyptes antipodes). New Zealand Journal of Zoology 17:201-212.

650

van Heezik Y., Davis LS. 1990. Effects of food variability on growth rates, fledging sizes and

651 reproductive success in the Yellow-eyed Penguin Megadyptes antipodes. Ibis 132:354-365.

652

Hocken AG. 2005. Necropsy findings in yellow-eyed penguins (Megadyptes antipodes) from Otago, New Zealand. New Zealand Journal of Zoology 32:1-8. DOI: 10.1080/03014223.2005.9518391.

Houston DM., Hocken AG. 2005. Diphtheritic stomatitis in yellow-eyed penguins. New Zealand 655 Journal of Zoology 32:263-271.

Jones DOB., Yool A., Wei C-L., Henson SA., Ruhl HA., Watson RA., Gehlen M. 2014. Global reductions in seafloor biomass in response to climate change. Global Change Biology 20:1861-1872. DOI:

658 10.1111/gcb.12480.

659

King SD. 2008. Breeding success of Yellow-eyed penguins on Stewart Island and off-shore islands

660 2003-2008. unpublished report: Yellow-Eyed Penguin Trust, Dunedin, New Zealand.

661

662

663

Kriticos DJ., Webber BL., Leriche A., Ota N., Macadam I., Bathols J., Scott JK. 2012. CliMond: Global high-resolution historical and future scenario climate surfaces for bioclimatic modelling. Methods in Ecology and Evolution 3:53-64. DOI: 10.1111/j.2041-210X.2011.00134.x. hookeri) as a threat to the viability of yellow-eyed penguins (Megadyptes antipodes) at Otago Peninsula, New Zealand. Biological Conservation 135:235-246. 
667 Limmer B., Becker PH. 2009. Improvement in chick provisioning with parental experience in a 668 seabird. Animal Behaviour 77:1095-1101.

669 Mattern T., Ellenberg U., Houston DM., Davis LS. 2007. Consistent foraging routes and benthic 670 foraging behaviour in yellow-eyed penguins. Marine Ecology Progress Series 343:295-306.

671 Mattern T., Ellenberg U., Houston DM., Lamare M., Davis LS., van Heezik Y., Seddon PJ. 2013. Straight 672 line foraging in yellow-eyed penguins: new insights into cascading fisheries effects and 673 orientation capabilities of marine predators. PloS ONE 8:e84381.

674 McClung MR., Seddon PJ., Massaro M., Setiawan AN. 2004. Nature-based tourism impacts on yellow675 eyed penguins Megadyptes antipodes: does unregulated visitor access affect fledging weight 676 and juvenile survival? Biological Conservation 119:279-285.

677

678

679

680 681 682 683 684 685 686 687 688 689

Mesnil B., Cotter J., Fryer RJ., Needle CL., Trenkel VM. 2009. A review of fishery-independent assessment models, and initial evaluation based on simulated data. Aquatic Living Resources 22:207-216. DOI: $10.1051 / \mathrm{alr} / 2009003$.

Moore PJ., Wakelin MD. 1997. Diet of the Yellow-eyed penguin Megadyptes antipodes, South Island, New Zealand, 1991-1993. Marine Ornithology 25:17-29.

Nisbet ICT., Dann P. 2009. Reproductive performance of little penguins Eudyptula minor in relation to year, age, pair-bond duration, breeding date and individual quality. Journal of Avian Biology 40:296-308.

Oliver ECJ., Wotherspoon SJ., Chamberlain MA., Holbrook NJ. 2014. Projected Tasman Sea Extremes in Sea Surface Temperature through the Twenty-First Century. Journal of Climate 27:19801998.

Opdam P., Wascher D. 2004. Climate change meets habitat fragmentation: linking landscape and biogeographical scale levels in research and conservation. Biological Conservation 117:285- 
691 Parmesan C., Yohe G. 2003. A globally coherent fingerprint of climate change impacts across natural 692 systems. Nature 421:37-42. DOI: 10.1038/nature01286.

693 Peacock L., Paulin M., Darby JT. 2000. Investigations into the climate influence on population 694 dynamics of yellow-eyed penguins Megadyptes antipodes. New Zealand Journal of Zoology $695 \quad 27: 317-325$.

696

697

698

700

701

702

703

704

705

706

707

708

709

710

711

Perriman L., Houston DM., Steen H., Johannesen E. 2000. Climate fluctuation effects on breeding of blue penguins (Eudyptula minor). New Zealand Journal of Zoology 27:261-267. DOI: 10.1080/03014223.2000.9518234.

Ratz H., Murphy B. 1999. Effects of habitat and introduced mammalian predators on the breeding success of Yellow-eyed Penguins Megadyptes antipodes, South Island, New Zealand. Pacific Conservation Biology 5:16-27.

Rawlence NJ., Perry GLW., Smith IWG., Scofield RP., Tennyson AJD., Matisoo-Smith EA., Boessenkool S., Austin JJ., Waters JM. 2015. Radiocarbon-dating and ancient DNA reveal rapid replacement of extinct prehistoric penguins. Quaternary Science Reviews 112:59-65. DOI: 10.1016/j.quascirev.2015.01.011.

Richard Y., Abraham ER. 2015. Assessment of the risk of commercial fisheries to New Zealand seabirds, 2006-07 to 2012-13. Wellington, New Zealand. Available at https://www.mpi.govt.nz/document-vault/10523

Richdale LE. 1949. A study of a group of penguins of known age. Dunedin, NZ: Otago Daily Times and Witness Newspapers Company.

Richdale LE. 1951. Sexual behavior in penguins. Lawrence, USA: University of Kansas Press. 
712 Richdale LE. 1957. A population study of penguins. Oxford, UK: Clarendon Press.

713 Robertson H., Dowding J., Elliott G., Hitchmough R., Miskelly C., O’Donnell C., Powlesland R., Sagar P.,

714 Scofield R., Taylor G. 2013. Conservation Status of New Zealand Birds, 2012. New Zealand

715 Threat Classification Series 4. Department of Conservation, Wellington, New Zealand

716 Seddon PJ., Ellenberg U., van Heezik Y. 2013. Yellow-eyed penguin (Megadyptes antipodes). In:

717 Garcia Borboroglu P, Boersma PD eds. Penguins: Natural History and Conservation. Seattle \&

718 London: University of Washington Press, 91-110.

719 Sekercioglu CH., Schneider SH., Fay JP., Loarie SR. 2008. Climate change, elevational range shifts,

$720 \quad$ and bird extinctions. Conservation Biology 22:140-150.

721 Sexton JP., McIntyre PJ., Angert AL., Rice KJ. 2009. Evolution and ecology of species range limits.

722 Annual Review of Ecology, Evolution, and Systematics 40:415-436. DOI:

$723 \quad$ 10.1146/annurev.ecolsys.l.

724 Shumway SE., Allen SM., Boersma PD. 2003. Marine birds and harmful algal blooms: Sporadic

725 victims or under-reported events? Harmful Algae 2:1-17. DOI: 10.1016/S1568-

$7269883(03) 00002-7$.

727 Sitas N., Baillie JEM., Isaac NJB. 2009. What are we saving? Developing a standardized approach for

728 conservation action. Animal Conservation 12:231-237. DOI: 10.1111/j.1469-

$729 \quad$ 1795.2009.00244.x.

730 Stocker TF. 2014. Climate change 2013: the physical science basis: Working Group I contribution to

731 the Fifth assessment report of the Intergovernmental Panel on Climate Change. Cambridge

$732 \quad$ University Press.

733 Sturrock HJW., Tompkins DM. 2007. Avian malaria (Plasmodium spp) in yellow-eyed penguins: 
734 Investigating the cause of high seroprevalence but low observed infection. New Zealand 735 Veterinary Journal 55:158-160. DOI: 10.1080/00480169.2007.36761.

736 Takasuka A., Oozeki Y., Kubota H. 2008. Multi-species regime shifts reflected in spawning

737 temperature optima of small pelagic fish in the western North Pacific. Marine Ecology Progress

$738 \quad$ Series $360: 211$.

739 Tang S., Chen L. 2002. Density-dependent birth rate, birth pulses and their population dynamic $740 \quad$ consequences. Journal of Mathematical Biology 44:185-199.

741 Tavecchia G., Tenan S., Pradel R., Igual JM., Genovart M., Oro D. 2016. Climate-driven vital rates do 742 not always mean climate-driven population. Global Change Biology 22:3960-3966. DOI: $743 \quad 10.1111 /$ gcb.13330.

744 Thomas CD., Cameron A., Green RE., Bakkenes M., Beaumont LJ., Collingham YC., Erasmus BFN., de 745 Siqueira MF., Grainger A., Hannah L., Hughes L., Huntley B., van Jaarsveld AS., Midgley GF., 746 Miles L., Ortega-Huerta MA., Townsend Peterson A., Phillips OL., Williams SE. 2004. Extinction $747 \quad$ risk from climate change. Nature 427:145-148.

748 Thuiller W., Lavorel S., Araújo MB. 2005. Niche properties and geographical extent as predictors of 749 species sensitivity to climate change. Global Ecology and Biogeography 14:347-357.

750 Tisdell C. 2007. Valuing the Otago Peninsula: The Economic Benefits of Conservation. Working

751 Papers on Economics, Ecology and the Environment, Vol 145. University of Queensland, 752 Brisbane, Australia.

753 Tompkins DM., Byrom AE., Pech RP. 2013. Predicted responses of invasive mammal communities to 754 climate-related changes in mast frequency in forest ecosystems. Ecological Applications 755 23:1075-1085. DOI: 10.1890/12-0915.1. 
756 Trathan PN., García-Borboroglu P., Boersma D., Bost C., Crawford RJM., Crossin GT., Cuthbert RJ.,

757 Dann P., Davis LS., De La Puente S. 2015. Pollution, habitat loss, fishing, and climate change as

758 critical threats to penguins. Conservation Biology 29:31-41.

759 Waters JM., Grosser S. 2016. Managing shifting species: Ancient DNA reveals conservation

760 conundrums in a dynamic world. BioEssays 38:1177-1184. DOI: 10.1002/bies.201600044.

761 Wilson K-J. 2004. Flight of the Huia: Ecology and conservation of New Zealand's frogs, reptiles, birds

762 and mammals. Canterbury University Press Christchurch.

763 Zimmer I., Ropert-Coudert Y., Kato A., Ancel A., Chiaradia A. 2011. Does foraging performance

764 change with age in female little penguins (Eudyptula minor)? PLoS ONE 6. DOI:

765 10.1371/journal.pone.0016098.

766 


\section{NEW ZEALAND}

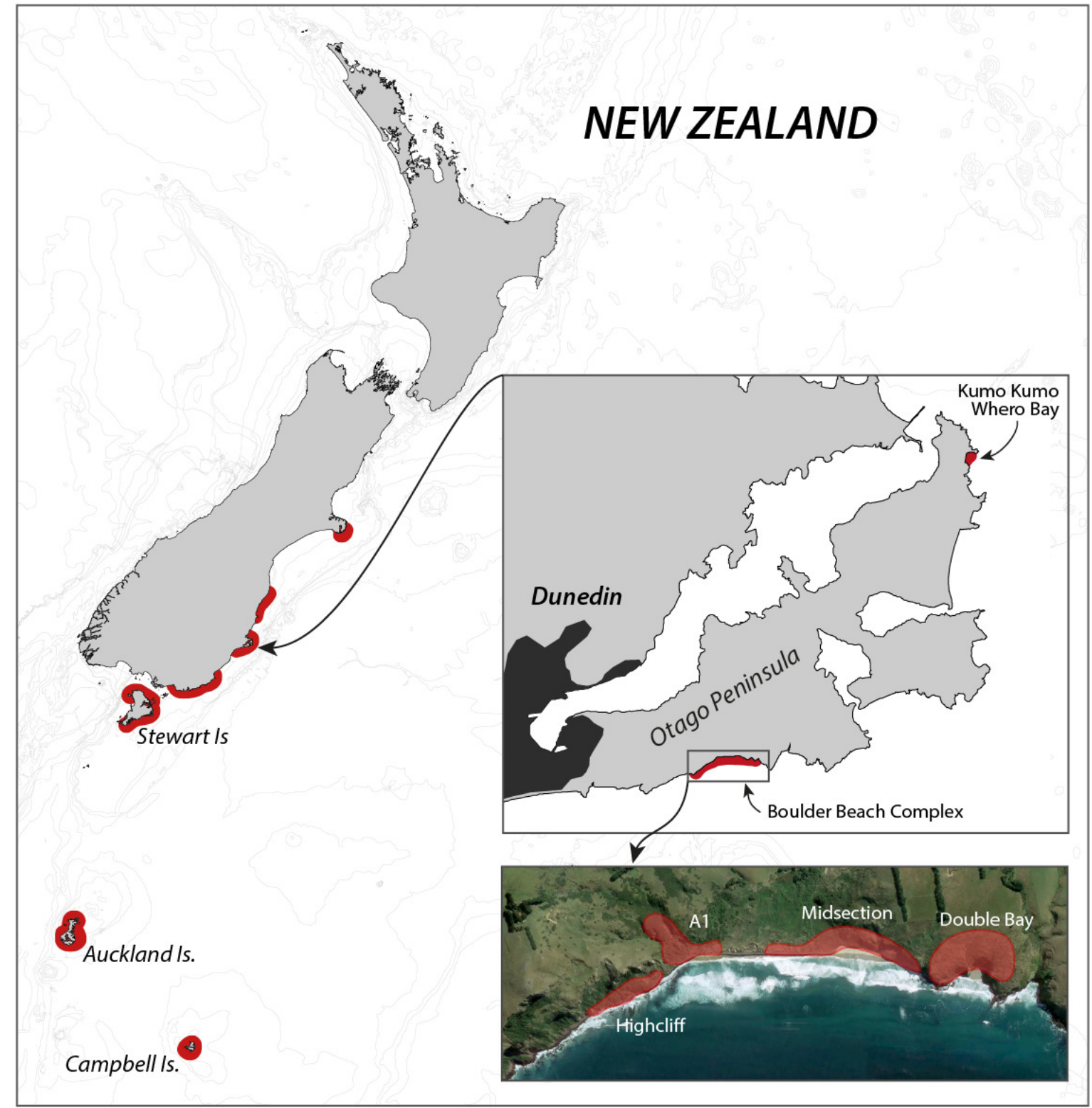

768 Figure 1. Overview of the breeding range of Yellow-eyed penguins, detail of the Otago

769 Peninsula with an aerial view of the Boulder Beach Complex (henceforth Boulder Beach)

770 with outlines indicating the locations of the four main monitoring plots. The inset map also

771 indicates Kumo Kumo Whero Bay, the location of the historic population study conducted

772 from the 1930 s to 1950 s. 


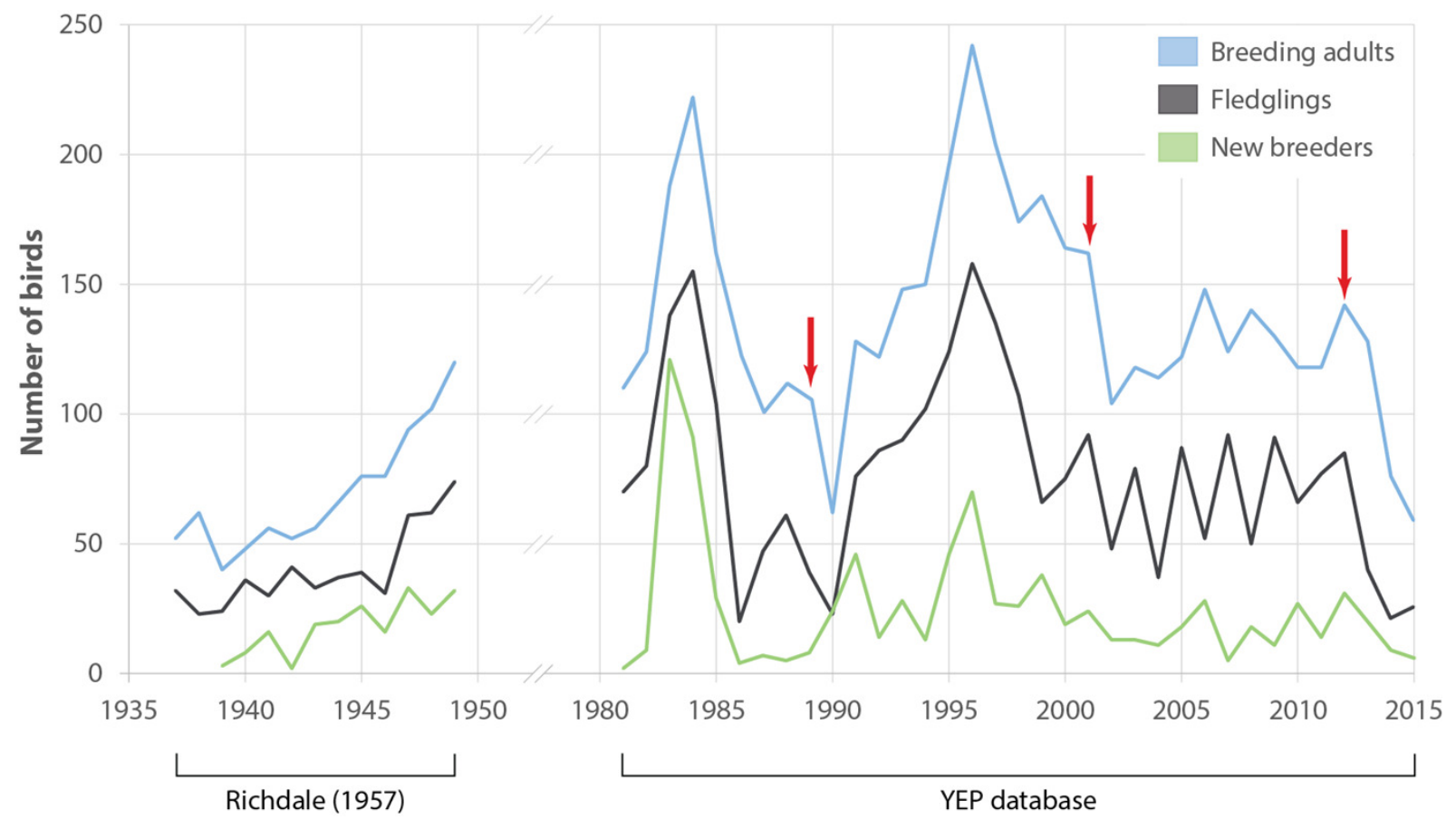

774 Figure 2. Observed penguin numbers at Kumo Kumo Whero 1937-1948 (from data

775 published in Richdale 1957, see Methods for details) and at the Boulder Beach complex

776 1982-2015 as extracted from the Yellow-eyed penguin database. 'New breeders' represents

777 the portion of all 'breeding adults' that were recorded as breeders for the first time. Red

778 arrows indicate years with observed die-off events affecting adult breeders. Note that as

779 some sections of the Boulder Beach complex were not monitored in all years, data for the

780 years 1986-1989 were adjusted by adding the mean proportion these areas contributed to

781 the total count in all other years. 


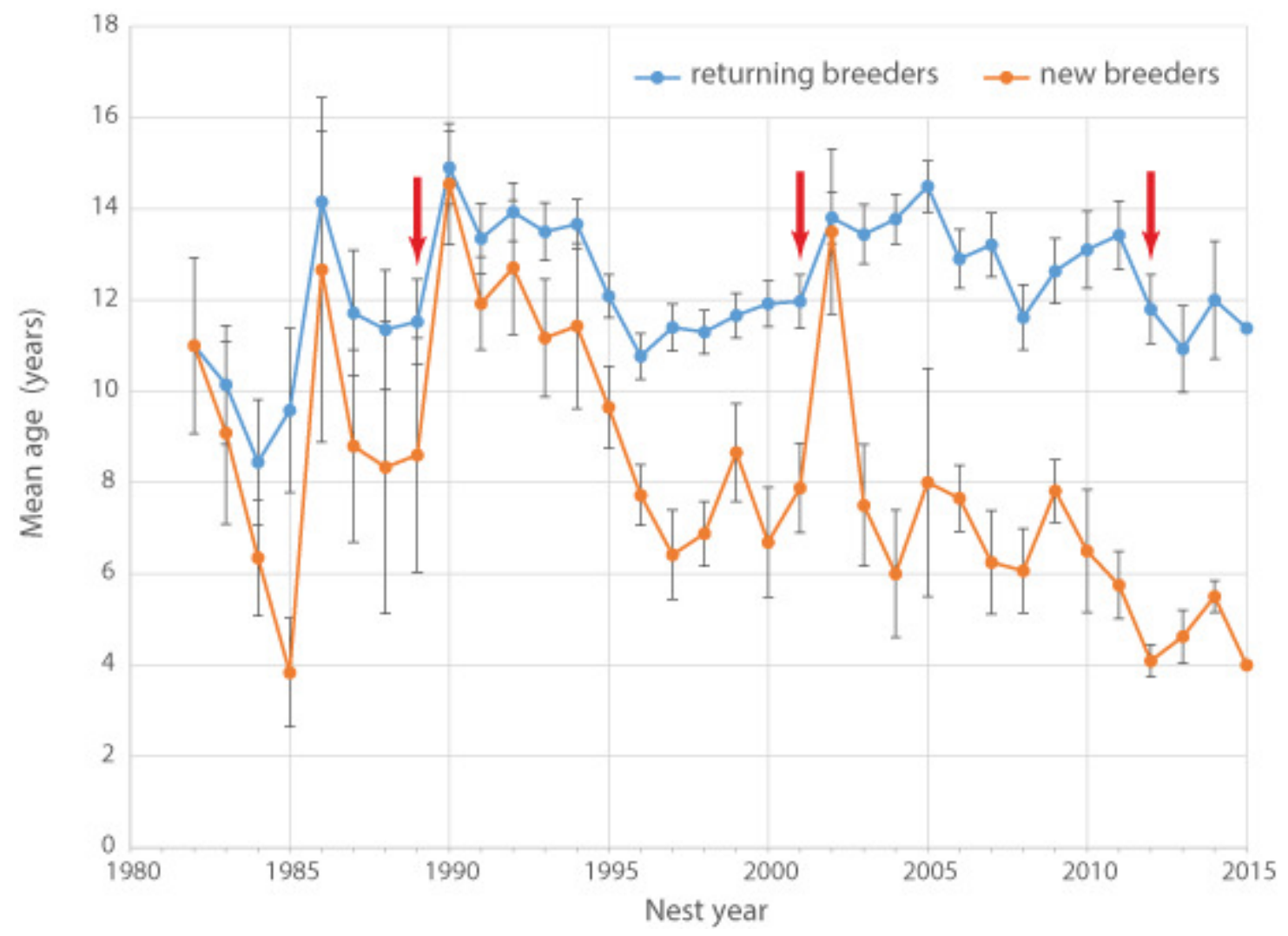

782

Figure 3. Average age of breeding Yellow-eyed penguins active at Boulder Beach between

7841982 and 2015. Red arrows indicate years with observed die-off events affecting adult

785 breeders. 


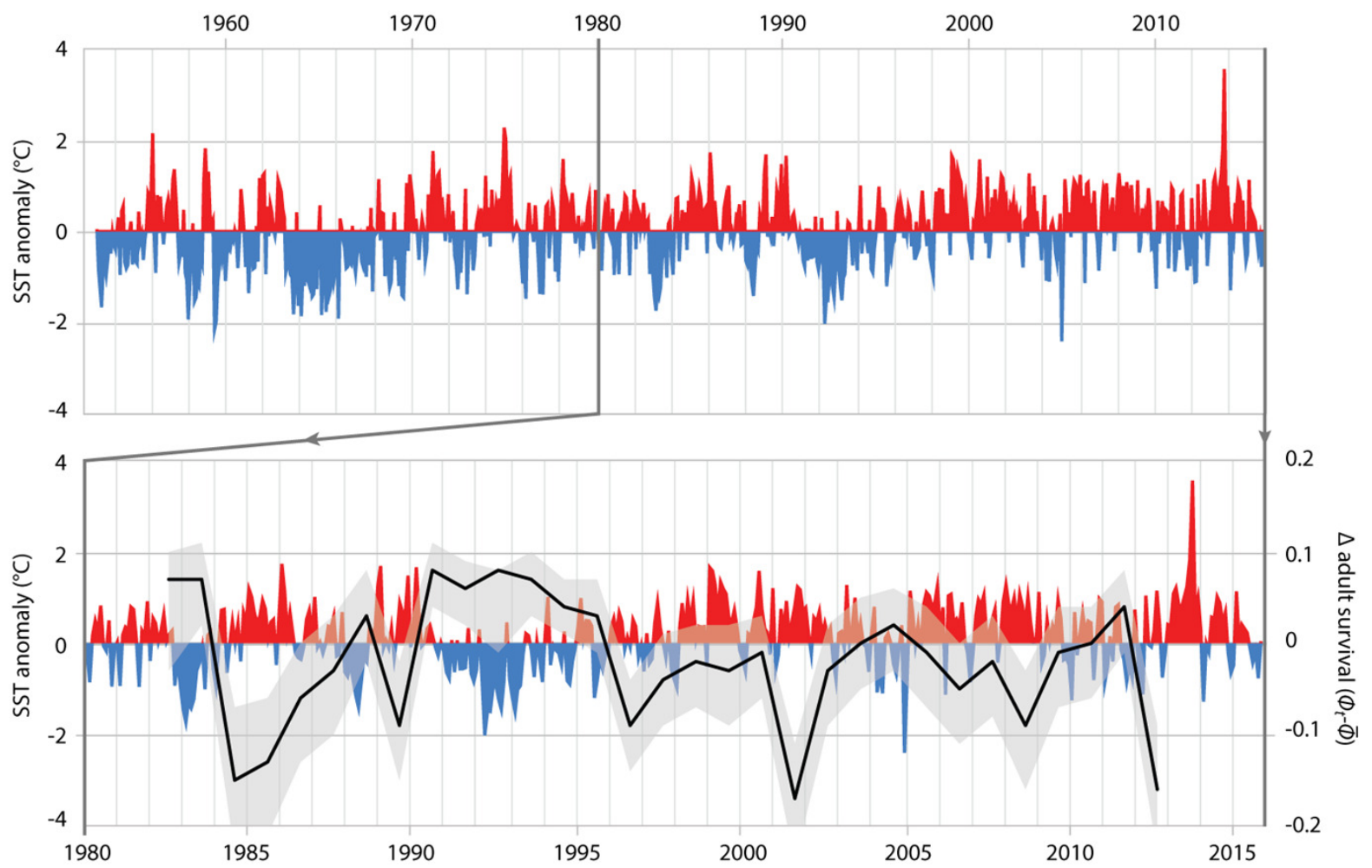

787 Figure 4. Top graph: Local Sea Surface Temperature anomalies recorded at Portobello

788 Marine Lab, Otago Peninsula, between 1953 and 2016. Bottom graph: detail of SST

789 anomalies 1980-2016 and associated deviance (black line: mean; grey area: 95\% credible

790 interval) in survival of adult Yellow-eyed penguins as determined from a MR recapture

791 model. 


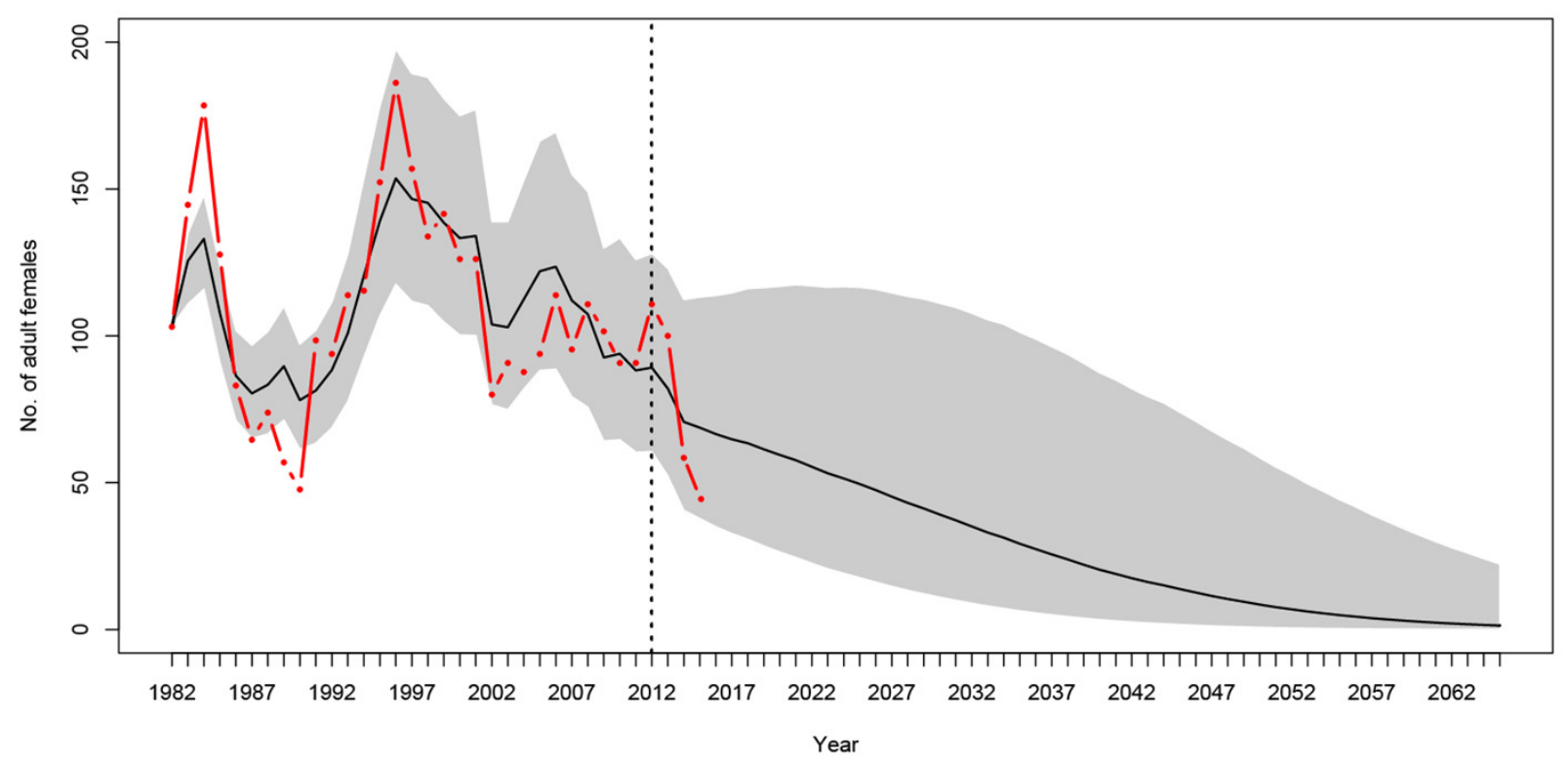

792

793 Figure 5. Population projections for Yellow-eyed penguins at Boulder Beach, Otago

794 Peninsula. The graphs show the observed (red line) and estimated (black line) number of

795 female penguins, and associated 95\% credible interval (grey area), as derived from the

796 population model. The dashed vertical line indicates the last year used to parameterise the

797 MR model and the starting year of the simulation. Population projections were modelled

798 using survival rate estimates until 2012; beyond this year estimates get increasingly

799 unreliable because these are based on data about individual absence from breeding rather

800 than from reported mortalities (see 'Methods'). 


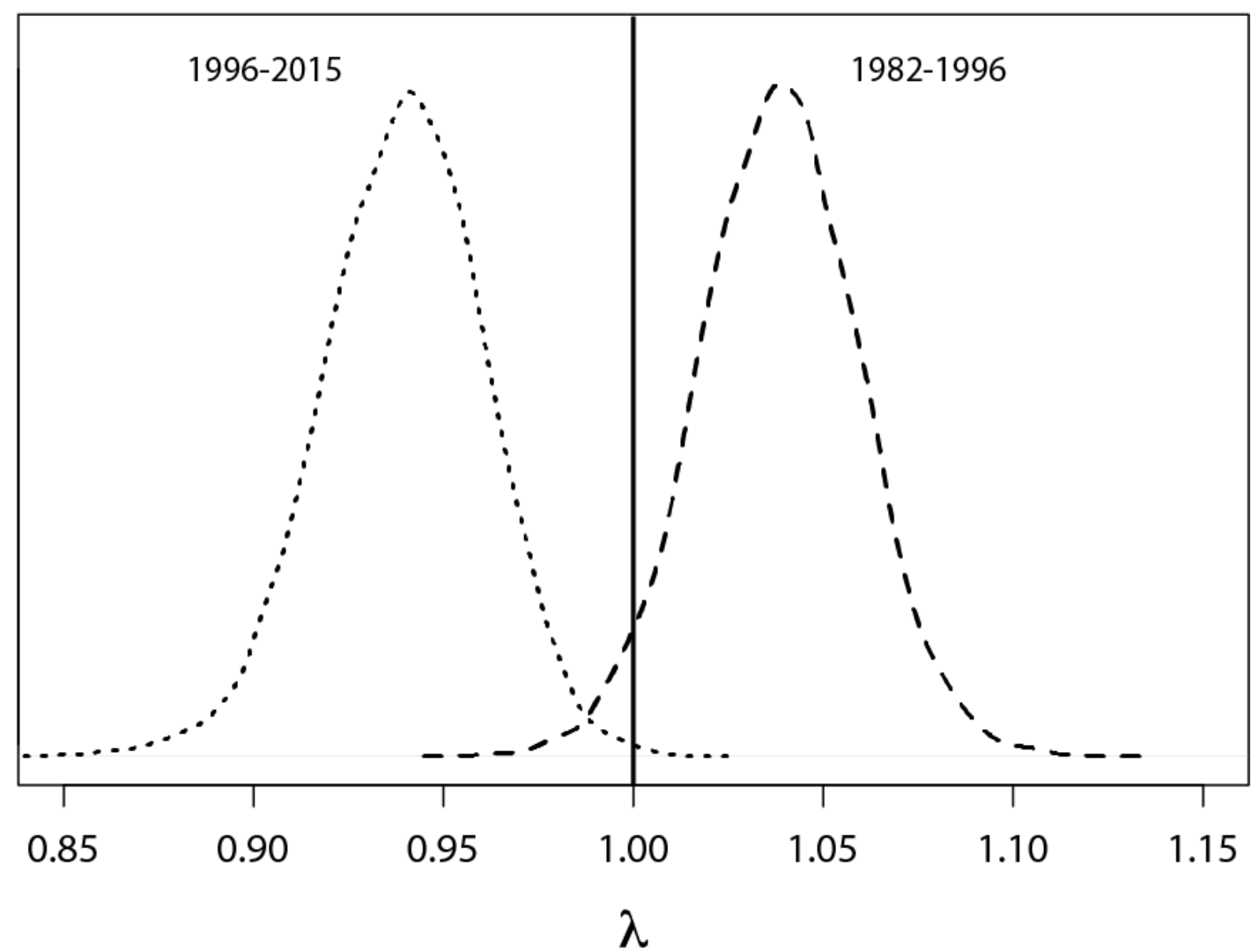

801

802 Figure 6. Probability density functions for deterministic annual population growth rates

803 derived from survival rates that were rescaled for periods of cooler (1982-1996) and

804 warmer (1996-2014) than average sea surface temperatures. 
805 Table 1. Description of basic environmental parameters used for the development of a YEP 806 population model.

\begin{tabular}{|l|l|l|}
\hline Parameter & shorthand & Station \\
\hline Total Rainfall (mm) & total_rainfall & $\begin{array}{l}\text { Southern Reservoir } \\
\text { (National Climate } \\
\text { database, CliFlo ID } \\
5400)\end{array}$ \\
\hline $\begin{array}{l}\text { Wet Days - Number Of } \\
\text { Days With 1mm Or More } \\
\text { Of Rain (days) }\end{array}$ & wet_days & $\begin{array}{l}\text { Southern Reservoir } \\
(5400)\end{array}$ \\
\hline $\begin{array}{l}\text { Maximum 1-Day Rainfall - } \\
\text { 9am To 9am Local Time }\end{array}$ & max_1day_rain & $\begin{array}{l}\text { Dunedin, Musselburgh } \\
(5402)\end{array}$ \\
\hline Mean Air Temperature & mean_air_temp & $\begin{array}{l}\text { Dunedin, Musselburgh } \\
(5402)\end{array}$ \\
\hline $\begin{array}{l}\text { Mean Daily Minimum Air } \\
\text { Temperature }\end{array}$ & daily_min_temp & $\begin{array}{l}\text { Dunedin, Musselburgh } \\
(5402)\end{array}$ \\
\hline $\begin{array}{l}\text { Days Of Wind Gusts >=33 } \\
\text { Knots }\end{array}$ & days_wind_gusts_33 & $\begin{array}{l}\text { Dunedin, Musselburgh } \\
(5402)\end{array}$ \\
\hline $\begin{array}{l}\text { Sea Surface Temperature } \\
\text { anomaly }\end{array}$ & sst_anomaly & $\begin{array}{l}\text { Portobello Marine Lab, } \\
\text { University of Otago }\end{array}$ \\
\hline
\end{tabular}


807 Table 2. Parameter estimates from the Bayesian mark-recapture model. $\Phi$ indicates

808 estimated annual survival rates, $\sigma^{2}$ stands for the temporal variance of the stage-specific 809 annual survival. Refer to ESM1 for details.

\begin{tabular}{|l|c|c|c|}
\hline & & \multicolumn{2}{|c|}{ Credible interval } \\
\hline Parameters & Median & $\mathbf{2 . 5 \%}$ & $\mathbf{9 7 . 5 \%}$ \\
\hline$\overline{\boldsymbol{\Phi}}_{\text {chicks }}$ & 0.124 & 0.077 & 0.189 \\
\hline $\boldsymbol{\sigma}_{\text {chicks }}^{2}$ & 1.877 & 1.001 & 3.847 \\
\hline $\boldsymbol{\sigma}_{\text {chicks }}^{2}$ (on probability scale) & 0.021 & 0.009 & 0.065 \\
\hline$\overline{\mathbf{\Phi}}_{\text {adults }}$ & 0.872 & 0.832 & 0.904 \\
\hline $\boldsymbol{\sigma}_{\text {adults }}^{\mathbf{2}}$ & 0.732 & 0.414 & 1.398 \\
\hline $\boldsymbol{\sigma}_{\text {adults }}^{\mathbf{2}}$ (on probability scale) & 0.009 & 0.005 & 0.021 \\
\hline
\end{tabular}


810 Table 3a. Estimated effect size for fledgling survival ( $\left.\beta_{\text {fledlings }}\right)$; PVE: percentage of variance 811 in fledgling survival explained by each covariate. Note, that negative values resulted from 812 models that estimated slightly higher (or less precise) variance in fledgling survival, as it 813 would result for the model without covariate. Except for covariate 2, 3, 4 and 15 all 814 variables were standardized before fitted to the MR model.

\begin{tabular}{|l|l|l|l|l|l|}
\hline \multirow{2}{*}{} & & \multicolumn{3}{|c|}{$\begin{array}{l}\text { Credible } \\
\text { interval }\end{array}$} \\
\hline ID & Covariate & Median & $\mathbf{2 . 5 \%}$ & $\mathbf{9 7 . 5 \%}$ & PVE \\
\hline 1 & days_wind_gusts_33_annual & 0.850 & 0.377 & 1.329 & 33.2 \\
\hline 2 & sst_anomaly_austral & -1.967 & -3.148 & -0.964 & 33.2 \\
\hline 3 & sst_anomaly_minus_1yr & -1.516 & -2.649 & -0.392 & 24.8 \\
\hline 4 & sst_anomaly_mar_june & -0.970 & -1.845 & -0.111 & 17.4 \\
\hline 5 & days_wind_gusts_33_mar_may & 0.696 & 0.198 & 1.241 & 16.5 \\
\hline 6 & daily_min_temp_annual & -0.644 & -1.190 & -0.143 & 15.4 \\
\hline 7 & mean_air_temp_annual & -0.590 & -1.167 & -0.102 & 12.4 \\
\hline 8 & daily_min_temp_mar_may & -0.303 & -0.829 & 0.204 & 0.7 \\
\hline 10 & mean_air_temp_mar_may & -0.304 & -0.850 & 0.190 & 0.2 \\
\hline 11 & total_rainfall_may_may & -0.254 & -0.823 & 0.296 & -2.3 \\
\hline 12 & max_1day_rain_mar_may & -0.250 & -0.835 & 0.318 & -3.3 \\
\hline 13 & total_rainfall_annual & -0.260 & -0.841 & 0.316 & -3.5 \\
\hline 14 & max_1day_rain_annual & -0.167 & -0.738 & 0.394 & -5.2 \\
\hline 15 & wet_days_mar_may & -0.141 & -0.702 & 0.431 & -5.6 \\
\hline 16 & sst_anomaly_minus_2yr & -0.217 & -1.451 & 1.045 & -5.6 \\
\hline & wet_days_annual & 0.073 & -0.461 & 0.623 & -6.7 \\
\hline
\end{tabular}


815 Table $3 \mathbf{b}$. Estimated effect size for adult survival ( $\beta_{\text {adults }}$ ); PVE: percentage of variance in 816 adult survival explained by each covariate. Note, that negative values resulted from models 817 that estimated slightly higher (or less precise) variance in adult survival, as it would result 818 for the model without covariate. Except for covariate 1, 4, 5 and 14 all variables were 819 standardized before fitted to the MR model.

\begin{tabular}{|l|l|l|l|l|l|}
\hline \multirow{2}{*}{} & & \multicolumn{3}{|c|}{$\begin{array}{l}\text { Credible } \\
\text { interval }\end{array}$} \\
\hline ID & Covariate & Median & $\mathbf{2 . 5 \%}$ & $\mathbf{9 7 . 5 \%}$ & PVE \\
\hline 1 & sst_anomaly_austral & -1.267 & -1.925 & -0.631 & 36.8 \\
\hline 2 & mean_air_temp_annual & -0.529 & -0.817 & -0.251 & 34.4 \\
\hline 3 & daily_min_temp_annual & -0.516 & -0.796 & -0.227 & 34.4 \\
\hline 4 & sst_anomaly_mar_june & -0.808 & -1.329 & -0.310 & 26.2 \\
\hline 5 & sst_anomaly_minus_1yr & -1.056 & -1.719 & -0.406 & 25.7 \\
\hline 6 & days_wind_gusts_33_annual & 0.377 & 0.075 & 0.690 & 16.5 \\
\hline 7 & days_wind_gusts_33_mar_may & 0.350 & 0.052 & 0.666 & 12.8 \\
\hline 8 & daily_min_temp_mar_may & -0.214 & -0.537 & 0.088 & 2.0 \\
\hline 9 & total_rainfall_may_may & -0.146 & -0.461 & 0.193 & 1.0 \\
\hline 10 & mean_air_temp_mar_may & -0.181 & -0.513 & 0.140 & -0.3 \\
\hline 11 & wet_days_mar_may & -0.113 & -0.434 & 0.207 & -1.0 \\
\hline 12 & max_1day_rain_mar_may & -0.098 & -0.416 & 0.234 & -2.0 \\
\hline 13 & max_1day_rain_annual & 0.112 & -0.206 & 0.435 & -2.2 \\
\hline 14 & sst_anomaly_minus_2yr & -0.055 & -0.867 & 0.720 & -3.1 \\
\hline 15 & wet_days_annual & 0.064 & -0.275 & 0.393 & -3.8 \\
\hline 16 & total_rainfall_annual & 0.057 & -0.268 & 0.391 & -4.0 \\
\hline
\end{tabular}


820 Table 4. Results of the Gibbs Variable Selection. 0 and 1 indicate whether each covariate is 821 not included or included in the model, respectively. The MR considers covariates

822 'sst_anomaly_austral' for fledgling (A) and adult survival (C), 'days_wind_gusts_33_annual' 823 (B) and 'mean_air_temp_annual' (D). For a detailed description of the GVS refer to ESM4.

\begin{tabular}{|c|c|c|c|c|c|}
\hline \multirow[b]{3}{*}{$\mathbf{M}_{\mathbf{i}}$} & \multicolumn{4}{|c|}{ Model configuration } & \multirow[b]{3}{*}{$\mathbf{p}\left(\mathbf{M}_{\mathrm{i}} \mid \mathbf{y}\right)$} \\
\hline & \multicolumn{2}{|c|}{ Fledgling survival } & \multicolumn{2}{|c|}{ Adult survival } & \\
\hline & A & B & C & $\mathbf{D}$ & \\
\hline 1 & 1 & 0 & 1 & 0 & 0.42 \\
\hline 2 & 0 & 1 & 1 & 0 & 0.13 \\
\hline 3 & 1 & 1 & 1 & 0 & 0.12 \\
\hline 4 & 1 & 0 & 0 & 1 & 0.09 \\
\hline 5 & 0 & 1 & 0 & 1 & 0.06 \\
\hline 6 & 0 & 0 & 0 & 0 & 0.04 \\
\hline 7 & 1 & 0 & 0 & 0 & 0.03 \\
\hline 8 & 0 & 1 & 0 & 0 & 0.03 \\
\hline 9 & 1 & 1 & 0 & 0 & 0.02 \\
\hline 10 & 0 & 0 & 1 & 0 & 0.01 \\
\hline 11 & 0 & 0 & 0 & 1 & 0.01 \\
\hline 12 & 1 & 1 & 0 & 1 & 0.01 \\
\hline 13 & 0 & 0 & 1 & 1 & 0 \\
\hline 14 & 1 & 0 & 1 & 1 & 0 \\
\hline 15 & 0 & 1 & 1 & 1 & 0 \\
\hline 16 & 1 & 1 & 1 & 1 & 0 \\
\hline
\end{tabular}

824 